\title{
School and Industries Collaboration on Implementing Vocational Education Internship Program: Best Practice in Indonesia
}

\author{
Marsono $^{1}$, Muhammad Rizki Muzani ${ }^{2}$, Basuki $^{3}$, Eddy Sutadji ${ }^{4}$, Yoto ${ }^{5}$, Siti Salina Mustakim ${ }^{6}, \mathrm{Pg} \mathrm{Hj}$ \\ Md Sufri bin Pg Hj Ali ${ }^{7}$ and Fitria Khasanah ${ }^{8}$ \\ 1,2,3,4,5 Department of Mechanical Engineering, Universitas Negeri Malang. Jl. Semarang 5, Malang, Indonesia \\ ${ }^{6}$ Department Foundation Studies, Universiti Putra Malaysia, 43400 UPM Serdang, Malaysia \\ ${ }^{7}$ Department of Academic Programme, Politeknik Brunei, Bandar Seri Begawan, BA1311, Brunei Darussalam \\ ${ }^{8}$ Department of Mathematic Education, University of Wisnuwardhana Malang, Malang, Indonesia \\ ${ }^{1}$ coresponding author: marsono.ft@um.ac.id
}

Keywords: collaboration, internship, industry, vocational school.

Abstract: This study aims to describe the collaboration of schools and industry in planning student internship program, implementing student internship program, and evaluating student internship program. This study uses descriptive methods with a qualitative approach. Correspondents in this study include the Chairperson of the Student Internship Program, Vice Principal of Public Relations, Vice Principal of Curriculum, Tutor of Student Internship Program, and Industry Representatives. The technique of collecting data are done by interviews, observations, and documentations. Data analysis uses data reduction, data presentation, and conclusion. To maintain the validity of the data, this study uses triangulation data collection techniques and data collection sources. The results of the study show that; 1) planning of vocational student internship program starting from school preparation which includes preparation of cooperation and administration in the form of letters, Memorandum of Understanding, and application proposals for student internship program; 2) The implementation of vocational student internship program includes placement of students in industries that are in accordance with competencies in schools, submission of students to industry, guidance of students by tutor, monitoring of students during practices, and student pick up; and 3) Evaluation of vocational student internship program is carried out by the school and industry.

\section{INTRODUCTION}

Vocational High Schools have an important role in produce students who are creative, skilled, and professional. In addition to being equipped with the knowledge taught in school, vocational students also study outside of school such as in industries and the business world that are in accordance with their fields. Studying at industries is an education and vocational skills training between education in schools with the mastery of skills acquired through direct practice in the business world so that they have qualified and capable skills (Vien, 2018). Therefore, the knowledge obtained at school is practiced directly into the field or industry and students do not feel awkward when they graduate and work in the industry.

Nurharjadmo (2008) states that vocational education is one form of implementation of "link and match" between the world of education and the world of work with an emphasis on professional expertise that combines systematically and synchronously between educational programs in schools with expertise programs obtained directly in the company. That means the system in vocational education has indeed been arranged so that students will be accustomed to going directly into the world of work.

If there is no provision of work experience during school, students will have difficulty in competing in the world of work after graduation and even students are not ready to work (Yoonjoung Heo et al., 2018). Yulianto and Sutrisno (2014) also explained that the impression of vocational graduates still not ready for work is still in the community.

The efforts made by vocational school itself are to facilitate students in obtaining knowledge and 
skills both at school and at industries. Placing students in relevant industries in internship program is very important so that there are no misconceptions about what is learned in school and what is practiced at industries.

Vocational students are expected to be able to adapt to a work or industry environment so that they are able to grow mentally, knowledge and skills (Xiaohao \& Feifei, 2018). Collaboration between schools and industry must be maintained in order to smooth the internship program. Therefore, the industry must also realize that they have an important role to play in advancing national education especially in Vocational Schools.

However, in some industries it still considers that the implementation of internship program of vocational students is a burden for industries. This made the industry spend extra costs if they accepted street vendors, because their skills were still lacking or could be said to be zero. Doubts from the industry should be overcome by good communication from the parties involved, especially the school that cooperates. With good communication, the intended purpose will be easily understood by the Industry. So that the Industry can all out in accepting and guiding the internship students at their place.

In the implementation of internship program was not all goes smoothly as expected. Various obstacles sometimes arise such as industry readiness in accepting student internship, industry enthusiasm in helping the world of education, suitability of the field of expertise with the place of internship and also the limited availability of industries. There are several obstacles in the implementation of internship program, namely: 1) Diversity in the level of readiness and progress of Vocational Schools, 2) Not yet possessed of standard structure and expertise in industry, 3) There is no allocation of cost of human resource development in the industry, 4) the perception that internship program can benefit the industry concerned, and 5) the lack of awareness by the industry about improving efficiency, effectiveness and quality.

Debriefing about the knowledge and skills before carrying out internship program is very important, because it will all be a mental and material readiness that students will practice at industries (Nghia \& My Duyen, 2018). So that after graduating students become independent and have the competencies that provide them in competing in the world of work. In addition, in terms of the quality of the education system, it must also be improved, such as teaching staff and infrastructure. Management of school collaboration is also a benchmark that affects the competency of graduates produced.

\section{LITERATURE REVIEW}

Internship program are a form of organizing education and training organized by each Vocational High School to improve the competency of skills students have so that they can enter business in a professional manner (Yoto, 2012). Furthermore, Susana (2016) argues that internship program is a strategy for students so that the learning process can be directly through work (learning by doing) on real work and to facilitate students in sharpening skills according to their fields.

Suwarni (2015) states that internship program is manifestation of policies that are generally implemented in two places, namely in schools and industries with the aim of improving the quality of graduates to know about working or handling work well. In carrying out the internship program, in addition to providing benefits for students and schools, they also benefit for industries. According to Yoto (2012) the implementation of internship program for vocational students in the industry provides great benefits for the industry, including: (a) can recognize the quality of students who study and work in the company. If industry assesses that the person can be an asset, industry can recruit into labour when they have finished. (b) In general, students have actively participated in the production process, so that within certain limits during the education period students are workers who can provide benefits. (c) During the education process in industry students are easily organized in disciplines according to the regulations. (d) Industry can assign assignments to students, to seek knowledge and technology from schools for the benefit of industry. (e) Giving satisfaction to industry because it was included to educate the nation and provide skills to determine the nation's future through the implementation of internship and the implementation of internship program.

\subsection{Internship Planning}

Planning is the initial activity before the implementation of an activity program, and basically planning is a framework of thinking about what is to be achieved, how to achieve and what and how many facilities are needed (Stedman et al., 2018). Planning can be said also as a decision-making 
success of students in mastering abilities and behaviour during internship program.

In addition to carrying out internship program in the industry, students are also required to make reports. The report contains the activities of students while carrying out practices in the industry. Reports are made in the form of journals of daily activities of students during internship program and signed by instructors from the industry.

Suwarni (2015) states that during field work there are daily activity journals that contain student developments during internship program. With the daily activity journal, the teacher will be able to see the activities of students during the implementation of internship program so that when the guidance teacher conducts guidance it will be easy to find out how much students are developing and the obstacles experienced by students during the implementation of internship program.

\section{RESEARCH METHODS}

The internship program is carried out based on the planning that has been made previously. The implementation of internship program is a Vocational High School curriculum program that must be taken that combines education programs in schools with the world of work. In the implementation of internship program must be done as well as possible to obtain the results expected by the school.

According to Suwarni (2015) in the implementation of internship program, the process or steps of implementing the internship must still refer to the design of the learning that has been set. The implementation of internship program includes: 1) bringing participants to the industry, 2) monitoring by guidance teachers, and 3) picking up students from the industry.

\subsection{Internship Evaluation}

Program evaluation cannot be carried out simultaneously, in detail and apply certain evaluation procedures so that the success of a program can be seen, and with evaluation there will be accurate information or data about the implementation of the program. Suartika et al., (2013) stated that the assessment of internship program included investigating the processes and results of student work while in the industry. The main assessment is how to determine the level of
The study used descriptive methods with a qualitative approach. This type of research is a case study. Subjects in the study were selected based on subject competencies that must be in accordance with the focus of the study, namely: (1) Chairperson of internship program, (2) Vice principle of School for Public Relations, (3) Vice Principal for Curriculum, (4) Teacher internship program, and (5) Industry Representatives.

The presence of researchers at research sites is very important because in qualitative research the position of researchers in the field is as the main research instrument. Data collection techniques are carried out by interview, documentation, and observation. The data analysis technique uses data reduction, data presentation, and conclusion drawing.

\subsection{Data Collection and Analysis}

Data collection techniques are procedures or steps in the research carried out with the aim of obtaining data. Without knowing and understanding the correct data collection techniques, the researcher will not get the right data and meet the standards set. If the data obtained is not in accordance with the standard set, the research data is considered invalid.

There are four types of data collection techniques direct observation in the field, in-depth interviews with speakers, documentation studies and a that can be done in qualitative research, namely: 
combination of the three (Fuad \& Nugroho, 2014). While in this study researchers obtained data through triangulation, namely, by interview, observation and documentation.

Moleong (2016) states that analyzing qualitative data is working with data, sorting, managing, synthesizing, looking for patterns and can express what is important to learn and express things that can be told to others. Usman and Purnomo (2003) suggest the steps in data analysis are reducing data, display data and the last is conclusions and verification. Whereas in qualitative research data analysis starts with writing problem formulation, collecting data, and drawing conclusions.

\section{FINDING AND DISCUSSION}

The results of the study found that the management of internship program of students in Vocational High Schools was as follows: 1) Planning of internship program of students in Vocational Schools, 2) Implementation of internship program of students in Vocational Schools, 3) Evaluation of internship program of students in Vocational Schools.

\subsection{Planning of Internship Program}

Planning internship program for Vocational students starts with school preparation which includes preparation for cooperation and administration in the form of letters, MoU, and application proposals for internship program, preparation of facilities and infrastructure, preparation of supervisors, and preparation for students. Suwarni (2015) also explained that the emphasis of the planning stage was on preparing data on the place of internship program, letter of approval to industry, and a letter of cooperation agreement from industry to receive prospective student participants in internship program.

Some of the criteria for determining industry that will be invited to work together are official and wellknown workshops, workshops that have previously collaborated with schools, which are relevant to students' competency needs, and industry locations that are not far from student residence or from school. The criteria that must be met for industries that cooperate with Vocational Schools include: (1) a minimum national scale industry, (2) industries willing to work together, and (3) work fields in accordance with the competencies opened in schools. Basically, industrial cooperation with
Vocational Schools can shape the character of students to fit the needs and realities of industry.

Miswardi and Pardjono, (2013) said that the industry must also prepare instructors or field supervisors for and also facilities and infrastructure that support students in the internship program. Instructors in the industrial world have roles as instructors, models, and instructors of certain skills that students do not get at school. Industrial instructors have the task of giving direction, guidance, giving new knowledge, practicing skills that have never been experienced by apprentice students when in school, as well as providing an assessment of student apprenticeship results.

The preparation that needs to be done by students includes preparation of attitude, mentality, skills and skills. Providing additional material for students, psychological debriefing, socialization of internship program is also very necessary. The first preparation before carrying out internship program is the preparation of students as potential participants in the industry's own internship program (Suwarni, 2015).

\subsection{Implementation of Internship Program}

The internship program of vocational students includes placement of students in the industry that are in accordance with the competencies in the school, submission of students to industry, guidance of students by supervisors in internship program, supervision of students during internship program, and student pick-up. In the placement of students in internship program, there are several things that need to be considered by the school. That is the economic factor of the student, the location of the industry from the student's residence, the achievements and attitudes of the students in the school, and the wishes of the parents. Placement of students in internship program with a number of considerations, namely in accordance with the majors taken at school, industry location where field work is not far from the district, school location, student economic level, and parental support.

The process of submitting students to internship program is through a tutor teacher. The tutor teacher delivers and submits students to industry at least one week before the implementation of internship program. The guiding teacher comes along with students to deliver and introduce students to the industry in the internship program. Similar statements are elaborated in the results of research conducted by Suwarni (2015) which states that the 
departure of students in the internship program is delivered by the guidance teacher.

Guidance by the supervising teacher from the school is carried out three times during the internship program. The first is coaching before students carry out internship program which are debriefing. This guidance process is carried out when taking students to industry. The second is guidance internship program carried out during monitoring activities. The latter is coaching when the end of the period of internship program.

The process of supervising students in internship program is carried out during the implementation of internship program. Supervision is carried out by two parties, namely from the school and industry. Student supervision includes activeness, discipline, and student competency development. This is in line with Suwarni (2015) which states that the implementation of monitoring is carried out by supervisors and the working group team. While the time of implementation is when students carry out internship program at industry.

The process of picking up the students' vocational internship program is carried out by the guidance teacher who has been assigned by the school. The time for pick-up can be done one week before the end of the internship program. The same thing was conveyed by Susana (2016) that supervisors formally withdraw students in the days leading up to the end of the internship program even though students must continue to complete internship program until a predetermined time. The flexibility of withdrawal is usually done because of the busy teacher and industry.

\subsection{Evaluation of Internship Program}

Evaluation of internship program of Vocational students is carried out by the school and industry. The school only provides an assessment format, then the industry gives an assessment. The value given by industry is based on the aspects of the assessment determined by the school. The previous school had prepared a score sheet which would be filled by industry. Research results Assessment of internship program students was given by industry in accordance with the assessment format prepared by the school. Another statement was expressed by Suartika et al., (2013) which states that the criteria and aspects of student assessment of internship program have been determined in the vocational curriculum. In the assessment of students' practical work, industry has full authority to provide assessments.
The aspects of evaluating internship program are divided into two, namely technical and non-technical aspects. Non-technical aspects include discipline, cooperation, communication, responsibility, honesty, customer service, cleanliness and safety. The technical aspects relate to students' competencies or skills and knowledge when doing work. Suartika (2013) states that the scope of assessment of internship program includes processes (nontechnical aspects) and student work outcomes (technical aspects) during internship program. The results of the research conducted by Mahmudi (2013) also stated that each internship participant will get an assessment at the end of the industrial internship program activities based on mastered competencies, discipline, and the responsibility of the students for the work given to them.

Reports are made by students based on what students do when practicing field work. The report format is provided by the school and students fill out the report. In preparing the report, students are guided by a supervising teacher. Reports are collected after the internship program is complete. Reports are also tested by industry so students get grades. Suwarni (2015) states that during field work there are daily activity journals that contain student developments during internship program. This is in accordance with the research conducted at the Vocational School, which is that every student is required to make a report containing the activities of students during the exercise of fieldwork. The reports made by students are of two types, namely the daily report which is a journal of students' daily activities and the final report made at the end of the implementation of internship program. The same thing was expressed by Sari et al., (2015) in the results of his research stating that student's internship program was proven by the existence of students' daily activity journals made during the implementation of internship program.

The certificate of internship program is given after the period ends and the student already has an industry score. The internship certificate contains technical and non-technical assessments provided by industry and graduation statements of students' internship program. There are two field work certificates, namely a certificate from industry and a certificate made by the school with an assessment from industry. Every student who has carried out internship program will get proof that the student has finished implementing an internship program in the form of a certificate. 


\section{CONCLUSIONS}

Research on school collaboration with industry in the implementation of internship program of vocational students, can be summarized as follows: (1) planning of internship program begins with the preparation of school collaboration with industry. School sent a proposal and letter of application for internship program to industry. An MoU was made if between the school and industry had agreed to cooperate in the internship program. The industry criteria as a location for internship program be in accordance with the competencies in the school and also good in guiding students to internship program. The supervisor of internship program must understand the rules, profile of industry being taught, and the character of the students. For industries that are the location of internship program must prepare instructors or people who can guide and nurture students when practicing internship program. The provision of additional material is very important so that students are more mature in theory and practice before going directly to industry. This will be further supported if the learning facilities and infrastructure of students in schools are better addressed and equipped. Common obstacles in internship program are due to students 'economic factors and students' readiness in competence. The steps that can be taken by the school to overcome it are by meeting and discussing with parents / guardians of students so that a good solution is obtained for students, and schools can better mature students' theories and skills in additional lessons especially in practice; (2) the implementation of internship program starts from the placement of students to industry. Then there is the handover of students to industry conducted by the tutor teacher. Guidance and supervision of students is carried out continuously by the guidance teacher and industry. Student supervision includes activeness, discipline and development of these students. At the end of the internship program the guidance teacher came to industry. Constraints that commonly occur in the implementation of internship program are about the discipline of students at industry. The steps taken by the school are by giving warnings and warnings to students and if they are still continuing, they will be given sanctions according to existing regulations; (3) evaluation of internship program of vocational students conducted by schools and industry. The value given by the industry to students is based on the aspects of assessment that have been determined by the school. In preparing the report students also make a paper whose contents are detailed elaboration of a job during internship program. Providing certificates for internship program is carried out by schools based on the value of industry. There are also several industries that provide certificates according to their own format. A common obstacle to evaluating internship program is the problem of time to request a certificate to industry because it can take school hours. For this reason, the guidance teacher can find time and ask for his own legalization to industry.

\section{REFERENCES}

Fuad, A., \& Nugroho, K. S. (2014). Panduan Praktis Penelitian Kualitatif. Yogyakarta: Graha Ilmu.

Mahmudi, M. (2013). Pelaksanaan Pendidikan Sistem Ganda Bersertifikat ISO di SMK Negeri 1 Malang. Jurnal Kebijakan dan Pengembangan Pendidikan, 1(2), 101-111.

Miswardi, Y., \& Pardjono. (2013). Proses dan Hasil Belajar pada Prakerin Bidang Keahlian Kendaraan Ringan: Studi Kasus Pada Industri Pasangan SMKN 3 Yogyakarta. Jurnal Pendidikan Vokasi, 3(2), 268-281.

Moleong, L. (2005). Metodologi Penelitian Kualitatif. Bandung: PT. Remaja Rosdakarya.

Nghia, T. L. H., \& My Duyen, N. T. (2018). Internshiprelated learning outcomes and their influential factors. Education + Training, 60(1), 69-81.

Nurharjadmo, W. (2008). Evaluasi Implementasi Kebijakan Pendidikan Sistem Ganda Di Sekolah Kejuruan. Jurnal Spirit Publik, 4(2), 215-228.

Sari, M. V. A., Sobri, A.Y., \& Triwiyanto, T. (2015). Strategi Sekolah untuk Meningkatkan Peluang Kerja Lulusan SMK Negeri 4 Malang. Retrieved from ap.fip.um.ac.id/.../1.-artikel-strategi-sekolah-untukmeningkatkan-peluang kerja-2.pdf

Stedman, J. M., McGeary, C. A., \& Essery, J. (2018). Current Patterns of Training in Personality Assessment During Internship. Journal of Clinical Psychology, 74(3), 398-406.

Suartika, Dantes., \& Candiasa. (2013). Studi Evaluasi Pelaksanaan Program Praktik Kerja Industri (Prakerin) dalam Kaitanya dengan Pendidikan Sistem Ganda Di SMK Negeri 1 Susut. e-Jurnal Program Pascasarjana Universitas Pendidikan Ganesha, 3(1).

Sugiyono. (2011). Metode Penelitian Kombinasi (Mixed Methods). Bandung: Alfabeta.

Susana, N. (2016). Pengelolaan Praktik Kerja Industri. Jurnal Manajer Pendidikan, 10 (6), 579-587.

Suwarni. (2015). Manajemen Praktik Kerja Industri. Jurnal Manajer Pendidikan, 9(1), 1-14.

Usman, H. \& Purnomo, S. A. (2003). Metodologi Penelitian Sosial. Jakarta: PT Bumi Aksara.

Vien, C. L. (2018). Powerful internship programs for smaller firms. Journal of Accountancy, 226(6), 1-7.

Xiaohao, D., \& Feifei, Z. (2018). Returns to Chinese College Student Investment of Time in Internships and In-School Learning: A Theoretical Model and 
Empirical Analysis. Chinese Education \& Society, 51(4), 294-306.

Yoto. (2012). Partisipasi Masyarakat Industri Dalam Pelaksanaan Praktik Kerja Industri Bagi Siswa SMK. Jurnal Teknik Mesin, 20(2), 1-25.

Yoonjoung Heo, C., Kim, S. (Sam), \& Kim, B. (2018). Investigating the Impact of Relationship Quality During an Internship on Millennials' Career Decisions and Gender Differences. Journal of Hospitality \& Tourism Education, 30(2), 71-84.

Yulianto \& Sutrisno, B. (2014). Pengelolaan Kerjasama Sekolah dengan Dunia Usaha/Dunia Industri (Studi Kasus SMK Negeri 2 Kendal). Jurnal Pendidikan Ilmu Sosial, 24(1), 19-37. 